Jerzy Bieluk ${ }^{1}$, Dorota Łobos-Kotowska ${ }^{2}$

\title{
Kwoty mleczne jako przedmiot obrotu - wybrane zagadnienia
}

\section{Uwagi wprowadzające}

Niniejsze opracowanie stanowi próbę określenia zasad obrotu kwotami mlecznymi po zmianach wprowadzonych na podstawie ustawy z dnia 20 kwietnia $2004 \mathrm{r}$. o organizacji rynku mleka i przetworów mlecznych ${ }^{3}$. Zagadnienie to wchodzi w zakres niezwykle obszernej problematyki jurydycznej kwot mlecznych. Ramy niniejszego opracowania nie pozwalają na szczegółową analizę całości zagadnień związanych z tą problematyką. Uwzględniając złożoną konstrukcję kwot mlecznych, będącą wynikiem usytuowania jej na styku sfery cywilnoprawnej i publicznoprawnej, zasadniczą uwagę skoncentrowano na określeniu charakteru prawnego kwot mlecznych. $Z$ jednej strony bowiem nabycie uprawnień do kwot mlecznych następuje w administracyjnoprawnym trybie, $\mathrm{z}$ drugiej natomiast przepisy ustawy o organizacji rynku mleka i przetworów mlecznych dopuszczają cywilnoprawny obrót tymi uprawnieniami zarówno w drodze czynności inter vivos, jak i mortis causa. Zbycie gospodarstwa rolnego pociąga za sobą zmianę uprawnionego do kwoty mlecznej, ale możliwe jest także przeniesienie uprawnienia do kwoty mlecznej bez gospodarstwa rolnego, zarówno w drodze zbycia uprawnienia w sposób definitywny, jak i poprzez oddanie uprawnienia w używanie, a zatem w sposób tymczasowy. Ponadto prawo do kwoty mlecznej podlega dziedziczeniu ${ }^{4}$, z tym że dziedziczy je osoba lub osoby, które odziedziczyły gospodarstwo i które będą kontynuowały produkcję mleka.

Omawiana problematyka należy do zakresu prawa rolnego, ale usytuowana jest na styku prawa cywilnego i administracyjnego. Analiza owego krzyżowania się

\footnotetext{
Uniwersytet w Białymstoku.

Uniwersytet Śląski w Katowicach.

Tekst jedn. Dz.U. z 2009 r. Nr 11, poz. 65 z późn. zm.

Zgodnie z art. 26 ustawy z dnia 20.04.2004 r. o organizacji rynku mleka i przetworów mlecznych prawo do kwoty indywidualnej podlega dziedziczeniu - jednak sformułowanie to budzi wątpliwości, o czym w dalszej części artykułu.
} 
dwóch gałęzi prawa pozwala pokazać problemy praktyczne wyłaniające się przy stosowaniu ustawy o organizacji rynku mleka i przetworów mlecznych.

Podjęte zagadnienie nie było dotychczas przedmiotem szerszego zainteresowania polskiej literatury przedmiotu, jednak uwagi w tym zakresie znaleźć można w szeregu publikacji ${ }^{5}$. Również orzecznictwo nie wypowiadało się w pełnym zakresie na temat charakteru prawnego kwot mlecznych.

Kwoty mleczne zostały wprowadzone do wspólnej organizacji rynku mleka 2 kwietnia 1984 r. przepisami rozporządzenia Rady (WE) nr 856/846 i rozporządzenia Rady (WE) nr 857/847 , jako odpowiedź na nadwyżki w produkcji mleka i przetworów mlecznych na wspólnotowym rynku mleka. Powodowało to konieczność interwencji cenowej i co się z tym ściśle wiąże - konieczność ponoszenia znacznych wydatków z budżetu wspólnotowego. Zastosowane w latach siedemdziesiątych „opłaty współodpowiedzialności”, a następnie instrumenty „gwarantowanego progu" nie przyniosły w praktyce spodziewanych efektów i skłoniły prawodawcę europejskiego do odwołania się do sprawdzonego na rynku cukru instrumentu kwot produkcyjnych. Mechanizm ten polega na przyznawaniu producentom rolnym uprawnień do wprowadzenia do obrotu mleka i przetworów mlecznych w ilości wyznaczonej rozmiarem kwoty, bez konieczności ponoszenia z tego tytułu opłaty. W przypadku przekroczenia przez producenta przyznanej kwoty, ciąży na nim obowiązek wniesienia opłaty z tytułu nadwyżek. Jej wysokość powoduje ekonomiczną nieopłacalność produkcji w ilości ponadkwotowej.

Reforma rynków rolnych z 2007 r., której normatywnym wyrazem jest rozporządzenie Rady (WE) nr 1234/2007 z dnia 22 października 2007 r. ustanawiające wspólną organizację rynków rolnych oraz przepisy szczegółowe dotyczące niektórych produktów rolnych ${ }^{8}$, wprowadziła podejście horyzontalne, polegające na ujęciu całego regulowanego obszaru w jednym akcie prawnym. Powołane rozporządzenie wprowadziło szereg instytucji prawnych, które dotychczas znajdowały się poza regulacją europejskich rynków branżowych, włączono nowe rynki do unijnej regulacji, ujednolicono system dopłat do prywatnego przechowywania, wprowadzono Fundusz Tytoniowy. Przepisami nowego rozporządzenia utrzymano natomiast instrument kwotowania produkcji rolnej, w tym kwotowania produktów mleka i in-

Por. E. Tomkiewicz, Limitowanie produkcji w ustawodawstwie rolnym Wspólnoty Europejskiej, Warszawa 2002, s. 53 i n. oraz E. Tomkiewicz, Kwoty mleczne jako forma reglamentowania rolnej działalności gospodarczej, „Studia luridica Agraria" 2000, t. 1, s. 76 i n., jednak uwagi Autorki były formułowane w okresie, kiedy nieznany był jeszcze kształt przyszłej regulacji dotyczącej kwotowania produkcji mleka w Polsce; ponadto por. A. Oleszko, „Dziedziczenie” kwot produkcyjnych oraz płatności w rolnictwie, „Annales UMCS. sectio G” 2005-2006, vol. 5253; R. Pastuszko, Przekazanie gospodarstwa rolnego za emeryturę (rentę strukturalna) a przejście kwoty mlecznej na nabywcę w świetle praktyki notarialnej, „Rejent” 2005, nr 1, s. 113 i n.; Ł. Bobeł, Z problematyki prawnej obrotu kwotami mlecznymi w Polsce, „Przegląd Prawa Rolnego” 2006, nr 1, s. 71 i n., Transfer kwot mlecznych bez gospodarstwa w prawie polskim, „Przeglad Prawa Rolnego” 2007, nr 2, s. 271 i n. 
nych przetworów mlecznych ${ }^{9}$. Także zmiany wprowadzone w ramach przeglądu health check Wspólnej Polityki Rolnej ${ }^{10}$ do regulacji wspólnej organizacji rynku mocą rozporządzenia Rady (WE) nr 72/2009 w sprawie zmian we wspólnej polityce rolnej poprzez zmianę rozporządzeń (WE) nr 247/2006, (WE) nr 320/2006, (WE) nr 1405/2006, (WE) nr 1234/2007, (WE) nr 3/2008, oraz (WE) nr 479/89 uchylające rozporządzenia (EWG) nr 1883/78, (EWG) nr 1254/89, (EWG) nr 2247/89, (EWG) nt 2055/93, (WE) nr 1868/94, (WE) nr 2596/97, (WE) nr 1182/2005 i (WE) nr $315 / 2007^{11}$ nie przyniosły zasadniczych zmian w systemie kwotowania produkcji mlecznej, a przyjęte rozwiązania nie dotyczą istoty i charakteru prawnego kwot mlecznych $^{12}$.

Do polskiego ustawodawstwa kwoty mleczne zostały wprowadzone ustawą z dnia 6 września 2001 r. o regulacji rynku mleka i przetworów mlecznych ${ }^{13}$. Powołana ustawa przewidywała wdrożenie instrumentów wsparcia rynku mleka i jego przetworów w celu dostosowania go do standardów interwencji na tym rynku w UE. Mocą przepisów powołanej ustawy wprowadzono indywidualne kwoty mleczne, a na producentów i przetwórców nałożony został obowiązek prowadzenia miesięcznych rejestrów. Akcesja Polski do UE spowodowała konieczność wprowadzenia zmian w ustawie, a ponadtrzyletni okres obowiązywania jej przepisów pozwolił na dokonanie wstępnej oceny przyjętych w niej rozwiązań. W Polsce nie zastosowano jednej spójnej regulacji dotyczącej rynków rolnych, a zachowane zostało nadal podejście branżowe. Przykładem takiego podejścia jest między innymi ustawa o organizacji rynku mleka i przetworów mlecznych, która ma charakter ustawy kompetencyjnej, określa bowiem zadania i właściwość jednostek organizacyjnych oraz organów w zakresie organizacji rynku mleka i przetworów mlecznych. W powołanej ustawie uregulowane zostały także kwestie pozostawione do rozstrzygnię-

Z uwagi na przedłużające się negocjacje, zmiany w organizacji rynku mleka i przetworów mlecznych nie zostały wprowadzone mocą przepisów rozporządzenia Rady (WE) nr 1234/2007, a odrębnie: rozporządzeniem Rady (WE) nr 1152/2007 z 26.09.2007 r. zmieniającym rozporządzenie (WE) nr 1255/1999 w sprawie wspólnej organizacji rynku mleka i przetworów mlecznych oraz rozporządzeniem Rady (WE) nr 1153 z 26.09.2007 r. zmieniającym rozporządzenie (WE) nr 2597/97 ustanawiające dodatkowe zasady w sprawie wspólnej organizacji rynku mleka i przetworów mlecznych w odniesieniu do mleka spożywczego.

10 Health check rozumiany jest jako dostosowanie WPR do aktualnych realiów (rosnących cen rynkowych, zmian klimatycznych, globalizacji itp.). Przegląd WPR zakończył się przyjęciem porozumienia Rady Ministrów UE do spraw Rolnictwa i Rybołówstwa. W wyniku tych ustaleń na początku 2009 r. wprowadzono pakiet legislacyjny modyfikujacy dotychczasowe instrumenty WPR.

11 Dz. Urz. L. 30 z 31.01.2009, s. 16.

12 Zmiana wymagająca sygnalizacji to ograniczenie uprawnień państw członkowskich w zakresie przekazywania kwoty do rezerwy krajowej. Stosownie do znowelizowanego art. 72 ust. 2 rozporządzenia Rady (WE) nr 1234/2007 państwa członkowskie mogą zdecydować, czy i na jakich warunkach możliwe jest przekazywanie do rezerwy krajowej całości lub części niewykorzystanej kwoty, dopiero jeżeli producenci nie wprowadzą do obrotu ilości równej przynajmniej $85 \%$ ich kwoty indywidualnej podczas co najmniej jednego dwunastomiesięcznego okresu. Por. M. Stańko, Nowe elementy konstrukcyjne wsparcia rynkowego w ramach przeglądu health check na tle dyskusji o prawnych gwarancjach jednolitości rynku wewnętrznego produktów rolno-spożywczych, (w:) Ocena prawna wpływu health check na przyszłość Wspólnej Polityki Rolnej, Toruń 2010, s. 108-109. 
cia Państwom Członkowskim lub nieuregulowane przez przepisy rozporządzenia Rady (WE) nr 1234/2007 i rozporządzeń wykonawczych.

\section{Charakter prawny kwot mlecznych}

Charakter prawny kwot mlecznych wywołuje nadal wiele kontrowersji ${ }^{14}$. Indywidualna kwota mleczna jest uprawnieniem do wprowadzenia do obrotu określonej ilości mleka przez producenta mleka będącego zarówno dostawcą hurtowym, jak i bezpośrednim. Korelatem tego uprawnienia jest obowiązek nałożony mocą postanowień art. 10 ust. 1 pkt 1 ustawy na podmiot skupujący, a polegający na obowiązku skupu mleka wyłącznie od producentów posiadających indywidualne kwoty dla dostaw (dostawców hurtowych). Do dnia 29 lutego 2004 r. decyzje w sprawie przyznania indywidualnych kwot mlecznych w wysokości proporcjonalnej do ilości mleka wprowadzanego do obrotu w roku referencyjnym wydawali - na podstawie ustawy z dnia 6 września 2001 r. o regulacji rynku mleka i przetworów mlecznych - dyrektorzy oddziałów terenowych Agencji Rynku Rolnego. Decyzje te stanowiły podstawę pierwotnego nabycia prawa do indywidualnej kwoty mlecznej. Tryb nabycia pierwotnych uprawnień do kwot mlecznych uzasadnia ich zaliczenie do sfery publicznoprawnej. Zgodnie z art. 6a ustawy o regulacji rynku mleka i przetworów mlecznych indywidualne kwoty mleczne są uprawnieniem, którego źródłem jest decyzja administracyjna, a normatywną podstawą ich przyznania są przepisy administracyjne. Stosunek łączący Agencję Rynku Rolnego ${ }^{15}$ i producenta rolnego nie cechuje autonomiczność podmiotów. To bowiem Agencja w drodze decyzji administracyjnej władczo kształtuje sytuację prawną producenta rolnego, rozstrzygając o przyznaniu lub odmowie przyznania kwoty mlecznej.

Powstałe w administracyjnoprawnym trybie uprawnienia do indywidualnych kwot mlecznych mają jednak charakter majątkowy, są zbywalne i mogą być przedmiotem obrotu. Zgodnie z art. 22 ustawy o organizacji rynku mleka i przetworów mlecznych prawo do indywidualnej kwoty mlecznej lub jej części może być zbywane. Możliwość zbycia jest ograniczona podmiotowo. Nabywcą może być tylko producent w rozumieniu przepisów rozporządzenia Rady (WE) nr 1234/2007,

14 Na złożony i nie do końca zdefiniowany jurydycznie charakter kwot produkcyjnych zwraca uwage A. Oleszko, „Dziedziczenie” kwot produkcyjnych..., s. 112 i n.

15 Agencja Rynku Rolnego działa na podstawie ustawy z dnia 11.03.2004 r. o Agencji Rynku Rolnego i organizacji niektórych rynków rolnych, (Dz.U. z 2007 r. Nr 231, poz. 1702 z późn. zm.) oraz statutu nadanego w drodze rozporządzenia Ministra Rolnictwa i Rozwoju Wsi z dnia 7.02.2008 r. w sprawie nadania statutu Agencji Rynku Rolnego (Dz.U. Nr 30, poz. 181). Szerzej na temat Agencji Rynku Rolnego por. A. Stelmachowski, (w:) Prawo rolne, pod red. A. Stelmachowskiego, Warszawa 2009, s. 428 i n.; P. Wojciechowski, (w:) Prawo rolne, pod red. P. Czechowskiego, Warszawa 2011, s. 128 i n. Wobec braku orzecznictwa w odniesieniu do ARR, dla określenia jej statusu prawnego można posłużyć się orzeczeniami Naczelnego Sądu Administracyjnego określającymi status prawny ARiMR w sferze administracyjnoprawnej: wyrok NSA z dnia 8.06.2006 r., II GSK 63/06, Lex nr 190551; wyrok NSA z dnia 20.09.2006 r., II GSK 95/06, Lex nr 273687; postanowienie WSA w Warszawie z dnia 7.01.2005 r., III SA/Wa 1796/04, Lex nr 256431; postanowienie NSA z dnia 16.11.2006 r., II GSK 189/06, Lex nr 287939. 
do którego przepisów odsyła polski ustawodawca. Umowa wymaga zatwierdzenia, w drodze decyzji, przez właściwego miejscowo dla zbywcy dyrektora oddziału terenowego Agencji. Ograniczenia obrotu kwotami mlecznymi nie wpływają natomiast na zasadniczą cechę kwot mlecznych - ich zbywalność i możliwość uzyskania w związku z tym korzyści majątkowych. Ustawodawca stwierdza wyraźnie, iż kwoty mleczne mogą być przedmiotem zbycia w drodze umowy. Zgodnie $\mathrm{z}$ art. 22 ust. 14 ustawy w sprawach nieuregulowanych do umowy zbycia kwoty indywidualnej stosuje się odpowiednio przepisy Kodeksu cywilnego dotyczące umowy sprzedaży. Należy więc uznać, iż poprzez uzyskanie wartości gospodarczej następuje nadanie przymiotu cywilnoprawnego uprawnieniu, którego źródłem jest decyzja administracyjna. Jest to więc prawo majątkowe, mające określoną wartość ekonomiczną, generujące powstawanie przychodu po stronie zbywcy uprawnienia.

W odniesieniu do kwot mlecznych występuje zatem pewna dwoistość ich charakteru prawnego, a uprawnienie do kwoty mlecznej winno być analizowane na dwóch płaszczyznach. Pierwszą z tych płaszczyzn wyznacza stosunek pomiędzy producentem i Agencją Rynku Rolnego, druga tworzy się pomiędzy producentami dokonującymi czynności obrotu. Stosunek prawny: producent - Agencja Rynku Rolnego ma z pewnością charakter administracyjnoprawny. Źródłem pierwotnego nabycia uprawnienia do indywidualnej kwoty mlecznej jest bowiem decyzja administracyjna. Także konwersja kwoty mlecznej z dostaw na sprzedaż bezpośrednią oraz ze sprzedaży bezpośredniej na dostawy, zgodnie z art. 24 ustawy o organizacji rynku mleka i przetworów mlecznych, wymaga decyzji, którą na podstawie wniosku producenta wydaje właściwy miejscowo dyrektor oddziału terenowego Agencji. W analizowanej relacji uprawnienie do indywidualnej kwoty mlecznej ma zatem charakter administracyjnoprawny i podlega zasadom prawa administracyjnego.

Jednak poprzez dopuszczenie do obrotu kwotami mlecznymi stały się one prawami o wartości majątkowej, które w ramach umowy sprzedaży lub oddania w używanie poddane zostały regulacji cywilnoprawnej, a podstawową cechą stosunków prawnych pomiędzy producentami jest równorzędność podmiotów. W stosunkach pomiędzy producentami uprawnienia do indywidualnych kwot mlecznych stają się zatem przedmiotem cywilnoprawnego obrotu.

Podobne stanowisko można odnaleźć w orzecznictwie sądów administracyjnych, które to uprawnienie do kwoty mlecznej kwalifikują, jako ewentualne prawo majątkowe, którego źródłem jest decyzja administracyjna, podkreślając jednocześnie, że prawa majątkowe są prawami podmiotowymi realizującymi interes ekonomiczny uprawnionego i składającymi się na jego majątek. Mają one wymiar pieniężny. ${ }^{16}$ 
Nieco podobnym do kwot mlecznych instrumentem są płatności uregulowane przepisami ustawy z dnia 26 stycznia 2007 r. o płatnościach w ramach systemów wsparcia bezpośredniego ${ }^{17}$. Rolnik występuje do Agencji Restrukturyzacji i Modernizacji Rolnictwa $\mathrm{z}$ wnioskiem o wydanie decyzji w sprawie przyznania płatności. Agencja (kierownik biura powiatowego ARiMR) w drodze decyzji administracyjnej kształtuje sytuację prawną rolnika, rozstrzygając o przyznaniu płatności lub odmawiając jej przyznania, przy uwzględnieniu ustawowych przesłanek. Postępowanie w sprawie przyznania płatności jest szczególnym postępowaniem administracyjnym, do którego stosuje się przepisy Kodeksu postępowania administracyjnego, z zastrzeżeniem odrębności przewidzianych ustawą o płatnościach w ramach systemów wsparcia bezpośredniego. W postępowaniu tym regulowane są stosunki administracyjnoprawne, przy czym postępowanie to mieści się w pojęciu indywidualnej sprawy $\mathrm{z}$ zakresu administracji publicznej, a rozstrzygnięcia zapadają $\mathrm{w}$ formach władczych, przewidzianych w postępowaniu administracyjnym ${ }^{18}$. Decyzje w sprawie płatności mogą zostać zaskarżone do dyrektora biura powiatowego ARiMR. Podlegają one również kontroli sądów administracyjnych. Uprawnienia do płatności bezpośrednich są zatem uprawnieniami, których źródłem jest decyzja administracyjna, a normatywną podstawą ich wypłaty są przepisy prawa administracyjnego. Zasadnicza różnica pomiędzy płatnościami i kwotami mlecznymi polega natomiast na wyłączeniu możliwości obrotu uprawnieniami do płatności. Nie można zatem uznać, iż płatności są instytucją prawa cywilnego. Ustawodawca tylko w szczególnych sytuacjach dopuszcza zmianę podmiotu uprawnionego do płatności, a zmiana ta łączyć się musi z przeniesieniem posiadania gruntów rolnych objętych wnioskiem. $\mathrm{W}$ przypadku zmiany podmiotu władającego gruntem, o podmiocie uprawnionym do otrzymania płatności nie decydują przepisy prawa cywilnego, a ustawy o płatnościach w ramach systemów wsparcia bezpośredniego ${ }^{19}$.

\section{Obrót kwotami mlecznymi}

Uprawnienia do kwot mlecznych mogą być przedmiotem obrotu. Zasadniczo, polski ustawodawca nie zdecydował się na zerwanie związku pomiędzy kwotą a gospodarstwem rolnym, wprowadzając regułę, że zbycie gospodarstwa prowadzi do przeniesienia kwoty mlecznej na nabywcę. Przepis art. 30 ust. 1 i 4 ustawy o orga-

17 Tekst jedn. Dz.U. z 2008 r. Nr 170, poz. 1051 z późn. zm.

18 Por. art. 3 ust. 1 ustawy o płatnościach w ramach systemów wsparcia bezpośredniego, który stanowi, że z zastrzeżeniem zasad i warunków określonych w przepisach Unii Europejskiej, o których mowa w art. 1 pkt 1 powołanej ustawy, do postępowań w sprawach indywidualnych rozstrzyganych w drodze decyzji stosuje się przepisy Kodeksu postępowania administracyjnego, chyba że przepisy ustawy stanowią inaczej. Konieczność pewnych uproszczeń procedury wynika m.in. z ilości wniosków wpływających corocznie do ARiMR - jest ich ponad 1.500 .000 .

19 Por. szerzej J. Bieluk, D. Łobos-Kotowska, Ustawa o płatnościach w ramach systemów wsparcia bezpośredniego. Komentarz, Warszawa 2008. s. 218 i n. oraz J. Bieluk, Charakter prawny płatności w systemie wsparcia bezpośredniego, (w:) Obrót gospodarczy w prawie rolnym, pod. red. B. Jeżyńskiej, Lublin 2009, s. 205 i n. 
nizacji rynku mleka i przetworów mlecznych stanowi, że w przypadku zbycia gospodarstwa producenta, przyznane mu prawo do indywidualnej ilości referencyjnej przechodzi na nabywcę gospodarstwa, a właściwy miejscowo dyrektor oddziału terenowego Agencji na podstawie wypisu aktu notarialnego albo kopii zawartej umowy dokonuje wpisu do rejestru producentów o przejściu prawa do indywidualnej ilości referencyjnej na nabywcę, dzierżawcę lub innego posiadacza zależnego gospodarstwa. Prawo to przechodzi na nabywcę w takim stanie, w jakim w dacie zbycia gospodarstwa przysługiwało ono zbywcy. Jeśli w dacie zbycia gospodarstwa kwota mleczna nie została wykorzystana w całości lub w części, to na nabywcę gospodarstwa przechodzi również kwota mleczna niewykorzystana w całości lub wykorzystana w części. Przejście prawa, o którym mowa w art. 30 ust. 4 ustawy, następuje ex lege, a wpis, którego dokonuje właściwy miejscowo dyrektor oddziału terenowego Agencji, ma jedynie charakter deklaratoryjny ${ }^{20}$.

Polski ustawodawca dopuścił także przeniesienie uprawnienia do kwot mlecznych bez gospodarstwa rolnego, przewidując w tym zakresie dwie dopuszczalne formy: zbycie kwoty mlecznej bez gospodarstwa rolnego oraz oddanie kwoty mlecznej do używania. Ustawodawca odmiennie kształtuje zatem sytuację prawną w zależności od tego, czy czynność prawna w sposób definitywny przenosi uprawnienie do indywidualnej ilości referencyjnej w drodze czynności zbycia, czy też czynność ta ma charakter tymczasowy i polega na oddaniu indywidualnej ilości referencyjnej jedynie do używania. W szczególności odmiennie określone zostały przesłanki nabycia uprawnienia do indywidualnej ilości referencyjnej.

\section{Zbycie kwot mlecznych}

W przypadku zbycia kwoty mlecznej bez jednoczesnego zbycia gospodarstwa rolnego ustawodawca określa przesłanki, które warunkują skuteczność takiej umowy. Zgodnie z art. 22 ust. 1 ustawy o organizacji rynku mleka i przetworów mlecznych, prawo do kwoty indywidualnej lub jej części może być zbywane wyłącznie producentowi, w drodze umowy zawartej w formie pisemnej, która dla swojej skuteczności wymaga zatwierdzenia, w drodze decyzji, przez właściwego miejscowo dla zbywcy dyrektora oddziału terenowego Agencji.

Umowa zbycia dotyczyć może zatem całej lub części kwoty przyznanej producentowi rolnemu $\mathrm{w}$ danym roku ${ }^{21}$, a jej przedmiotem może być wyłącznie niewykorzystana w danym roku kwotowym część kwoty mlecznej.

20 Por. wyrok WSA w Warszawie z dnia 20.09.2006 r., IV SA/Wa 1147/06, Lex nr 256683 oraz wyrok WSA w Warszawie z dnia 3.10.2006 r., IV SA/Wa 1163/06, Lex nr 283611.

21 Zrezygnowano z przesłanki regionalizacji kwot mlecznych. W dniu 1.04.2009 r. weszła bowiem w życie nowelizacja ustawy z 15.06.2007 r. o zmianie ustawy o organizacji rynku mleka i przetworów mlecznych oraz niektórych innych ustaw, Dz.U. Nr 115, poz. 794. 
Umowa powinna zostać zawarta z podmiotem posiadającym status prawny producenta, którego głównymi cechami jest to, że posiada gospodarstwo, zarządza nim i prowadzi działalność rolniczą. Znaczenie zwrotu ,producent rolny” ustalić należy przy uwzględnieniu przepisów rozporządzeń Rady (WE). Stosownie bowiem do brzmienia art. 31 ust 1 ustawy o organizacji rynku mleka i przetworów mlecznych pojęcie producenta należy definiować zgodnie $\mathrm{z}$ art. 65 lit. c rozporządzenia Rady (WE) nr 1234/2007. Zgodnie z powołanym przepisem producent oznacza rolnika, którego gospodarstwo jest położone na terytorium geograficznym państwa członkowskiego, a który produkuje i wprowadza do obrotu mleko lub który przygotowuje się do prowadzenia takiej działalności w najbliższej przyszłości. Z kolei powołany przepis art. 65 lit. d odwołuje się do definicji gospodarstwa rolnego zawartej w art. 2 lit. b rozporządzenia Rady (WE) nr 73/2009 z dnia 19 stycznia 2009 r. ustanawiającego wspólne zasady dla systemów wsparcia bezpośredniego dla rolników w ramach wspólnej polityki rolnej i ustanawiającego określone systemy wsparcia dla rolników, zmieniającego rozporządzenia (WE) nr 1290/2005, (WE) nr 247/2006, (WE) nr 378/2007 oraz uchylające rozporządzenie (WE) nr 1782/200322. Zgodnie z jego brzmieniem gospodarstwo oznacza wszystkie jednostki produkcyjne zarządzane przez rolnika, które znajdują się na terytorium tego samego Państwa Członkowskiego. Z powyższego wynika, że pojęcie gospodarstwa rolnego określone jest podmiotowo i związane jest $\mathrm{z}$ osobą prowadzącą to gospodarstwo, którą zgodnie $\mathrm{z}$ art. 2 lit. a może być osoba fizyczna lub prawna bądź grupa osób fizycznych lub prawnych, bez względu na status prawny takiej grupy i jej członków w świetle prawa krajowego, których gospodarstwo znajduje się na terytorium Wspólnoty, oraz które prowadzą działalność rolniczą. Ustawodawca wspólnotowy nie wymaga natomiast, aby wnioskujący o przyznanie kwoty mlecznej legitymował się tytułem prawnym do gruntów rolnych, a wystarczającym wydaje się posiadanie gospodarstwa rolnego. Skoro o dopuszczeniu transferów decyduje Państwo Członkowskie, to pojęcie posiadania gospodarstwa rolnego należy również wyprowadzić z prawa krajowego. W tym również pojęcia posiadacza samoistnego, czy też zależnego, poszukiwać należy w regulacjach Kodeksu cywilnego ${ }^{23}$. Analogicznie przyjąć należy, że do skutecznego zbycia kwoty mlecznej wystarczające jest posiadanie gospodarstwa rolnego, bez konieczności wykazania się tytułem prawnym do gruntu.

Do umowy zbycia uprawnienia do kwoty mlecznej w kwestiach nieuregulowanych stosuje się odpowiednio przepisy Kodeksu cywilnego. W szczególności należy wskazać na art. 555 Kodeksu cywilnego, zgodnie z którym przepisy o sprzedaży rzeczy stosuje się odpowiednio do sprzedaży energii oraz do sprzedaży praw ${ }^{24}$. Nie

Dz. Urz. L.30 z 31.01.2009, s. 16.

Por. wyrok WSA w Warszawie z dnia 6.12.2007 r., IV SA/Wa 1354/07, Lex nr 494035.

Por. Z. Gawlik, Komentarz do art. 555 Kodeksu cywilnego, program komputerowy Lex: Uzasadnione jest zatem postrzeganie art. $555 \mathrm{kc}$. w ten sposób, że dotyczy on wszystkich tych obiektów sprzedaży, które odróżniają się w swej istocie od rzeczy w rozumieniu art. $44 \mathrm{kc}$. 
stosujemy do niej przepisów dotyczących sprzedaży konsumenckiej, gdyż dotyczy ona rynku profesjonalnego.

Sprzedaż jest umową dwustronnie zobowiązującą. Skutkiem zawarcia umowy sprzedaży jest zobowiązanie się sprzedawcy do przeniesienia własności rzeczy lub prawa na kupującego oraz zobowiązanie się kupującego do zapłacenia sprzedawcy umówionej ceny. Jest to umowa konsensualna, odpłatna, kauzalna.

Umowa ta powoduje definitywne przeniesienie prawa na nabywcę. Umowa powinna być zawarta $\mathrm{w}$ formie pisemnej. Zgodnie z art. 73 § 1 Kodeksu cywilnego, jeżeli ustawa zastrzega dla czynności prawnej formę pisemną, czynność dokonana bez zachowania zastrzeżonej formy jest nieważna tylko wtedy, gdy ustawa przewiduje rygor nieważności. W odniesieniu do umowy zbycia uprawnienia do kwoty mlecznej ustawodawca rygoru nieważności co prawda nie przewidział, jednak nałożył na zbywcę obowiązek dostarczenia kopii umowy wraz z wnioskiem o zatwierdzenie umowy. Umowa ta wymaga bowiem dla swojej skuteczności zatwierdzenia jej w drodze decyzji wydanej przez dyrektora oddziału terenowego Agencji, na wniosek stron złożony w ustawowym terminie.

\section{Oddanie do używania}

Drugim sposobem przeniesienia uprawnienia do kwoty mlecznej bez gospodarstwa jest oddanie tej kwoty w używanie. Zasadniczo przedmiotem umowy może być wyłącznie część kwoty mlecznej, której oddający w używanie nie zamierza wykorzystać w danym roku kwotowym. Oddanie w używanie całej kwoty mlecznej jest natomiast dopuszczalne jedynie wyjątkowo. Stosownie do art. 22 a ustawy o organizacji rynku mleka i przetworów mlecznych oddanie w używanie całej kwoty mlecznej jest dopuszczalne wyłącznie w przypadkach określonych w art. 72 ust. 3 rozporządzenia Rady (WE) nr 1234/2007. W powołanym przepisie mowa jest o przypadkach działania siły wyższej oraz o innych należycie uzasadnionych i uznanych przez właściwy organ przypadkach tymczasowo wpływających na zdolność produkcyjną producentów. Umowa powinna być zawarta z producentem rolnym na okres roku kwotowego, a polski ustawodawca do trzech kolejnych lat kwotowych ograniczył możliwość oddawania do używania kwot mlecznych. Ponadto, identycznie jak w przypadku zbycia uprawnienia do kwoty mlecznej, także w przypadku przeniesienia uprawnienia do używania kwoty mlecznej umowa wymaga zatwierdzenia przez dyrektora oddziału terenowego Agencji Rynku Rolnego.

Określenie przedmiotu umowy jako oddanie w używanie może budzić kontrowersje, gdyż nie odpowiada terminologii stosowanej przez ustawodawcę na gruncie przepisów Kodeksu cywilnego. Przepisy Kodeksu konsekwentnie posługują się bo- 
wiem terminem oddanie do używania ${ }^{25}$. Zgodnie $\mathrm{z}$ art. 22a ustawy do umowy o oddanie w używanie stosuje się odpowiednio przepisy Kodeksu cywilnego dotyczące umowy dzierżawy. Odesłanie odbywa się poprzez art. 709 Kodeksu cywilnego, zgodnie z którym przepisy o dzierżawie rzeczy stosuje się odpowiednio do dzierżawy praw. Przyjąć należy, iż zastosowanie mają również pozostałe przepisy Kodeksu cywilnego o dzierżawie.

Umowa oddania w używanie - biorąc za punkt wyjścia regulację dotyczącą dzierżawy - jest umową dwustronnie zobowiązującą, konsensualną, wzajemną i odpłatną. Treścią umowy jest udostępnienie prawa do indywidualnej kwoty mlecznej na określonych warunkach - częściowo ściśle określonych przez ustawę o organizacji rynku mleka i przetworów mlecznych, na przykład jeżeli chodzi o czas udostępnienia uprawnienia. Osoba otrzymująca w używanie uprawnienie do kwoty mlecznej ma prawo do pożytków, w tym wypadku polegających na możliwości sprzedaży mleka w określonych ilościach. W art. 22a ust. 1 ustawodawca ustalił maksymalny czas trwania umowy, na jeden rok kwotowy. Podobnie jak w przypadku umowy zbycia wymagana jest forma pisemna.

\section{Skuteczność umów dotyczących kwot mlecznych}

Zgodnie $\mathrm{z}$ art. 22 ust. $1 \mathrm{i}$ art. 22a ust. 1 ustawy o organizacji rynku mleka i przetworów mlecznych, zarówno umowa zbycia, jak i umowa oddania w używanie uprawnienia do kwoty mlecznej, zawarta w formie pisemnej i spełniająca warunki przewidziane w ustawie, jest ważna, jednak dla swojej skuteczności wymaga zatwierdzenia przez dyrektora oddziału terenowego Agencji. Brak skuteczności takiej umowy nie może być utożsamiany z bezskutecznością zawieszoną w rozumieniu art. $63 \S 1 \mathrm{kc}$. Zgodzić się tu należy ze stanowiskiem, iż nieuzasadnione byłoby w świetle obowiązującego prawa, obejmowanie konstrukcją bezskuteczności zawieszonej przypadków, gdy przepis ustawy wymaga dla dokonania czynności prawnej zgody (zezwolenia) organu władzy publicznej (administracji, rządowej, samorządowej, sądu). Organy te występują w roli władczej i ani nie są w rozumieniu prawa cywilnego „osobami trzecimi”, ani nie składają „oświadczenia woli”, co konstytuuje zdarzenie wywołujące stan zawieszonej bezskuteczności ${ }^{26}$.

Wydaje się, że właściwszą konstrukcją byłoby wprowadzenie regulacji, w której decyzja o zatwierdzeniu umowy byłaby przesłanką ważności umowy cywilnoprawnej. Kwestię braku zgody na zawarcie umowy należałoby zatem rozpatrywać

Por. art. art. 659 Kodeksu cywilnego: §1. Przez umowę najmu wynajmujący zobowiązuje się oddać najemcy rzecz do używania przez czas oznaczony lub nie oznaczony, a najemca zobowiązuje się płacić wynajmującemu umówiony czynsz, por. też art. 693 § 1 . Przez umowę dzierżawy wydzierżawiający zobowiązuje się oddać dzierżawcy rzecz do używania i pobierania pożytków przez czas oznaczony lub nie oznaczony, a dzierżawca zobowiązuje się płacić wydzierżawiającemu umówiony czynsz. 
w kontekście sankcji przewidzianej w art. 58 Kodeksu cywilnego - czyli nieważności bezwzględnej.

Odrębną kwestią, wykraczającą poza ramy niniejszego opracowania, jest regulacja wpływu decyzji administracyjnej, a przede wszystkim jej nieważności, na ważność, czy też jak chce ustawodawca - skuteczność umowy cywilnoprawnej. Biorąc pod uwagę trudności interpretacyjne takiej sytuacji, należałoby postulować ustawowe rozwiązanie tego problemu.

\section{Wnioski}

Specyficzna dwoistość charakteru prawnego kwot mlecznych wywołuje pewne trudności interpretacyjne. Kwoty mleczne ze względu na swój rodowód mają charakter administracyjny. Są instytucją ze sfery publicznoprawnej. Dopuszczenie przez ustawodawcę obrotu uprawnieniami do kwot mlecznych nadało im wartości ekonomicznej, przez co stały się instrumentem przynależnym do sfery prywatnoprawnej. Czynności zbycia kwot mlecznych i ich oddania w używanie, mimo ustawowych ograniczeń, są z pewnością czynnościami cywilnoprawnymi, mającymi charakter rozporządzenia prawami majątkowymi. Przy analizie tych umów możemy posługiwać się dorobkiem prawa cywilnego, nie zapominając jednocześnie o specyficznym, administracyjnym rodowodzie ich przedmiotu. Odmienny charakter prawny mają płatności bezpośrednie. Płatności przynależą do sfery administracyjnej, a w związku z niedopuszczalnością wprowadzania ich do obrotu nie uzyskują przymiotu cywilnoprawnego. W przypadku, gdy polski ustawodawca, wzorem innych krajów Unii Europejskiej, dopuści również obrót również uprawnieniami do płatności, kwalifikacja prawna i charakter prawny obu uprawnień będzie podobny.

Regulacja prawna kwot mlecznych wymaga uzupełnienia o jasne rozwiązania prawne dotyczące sytuacji znajdujących się na styku prawa administracyjnego i cywilnego - przede wszystkim o kwestię wzajemnych relacji decyzji administracyjnych i umów. 


\section{Quotas for the production of milk as a subject of turnover - chosen issues}

Key words: Common Agricultural Policy, alienation, Agricultural Market Agency, quotas for the production of milk

Quotas for the production of milk are a permanent element of the Common Agricultural Policy. Their legal character and the possibility of their acquisition are the subject of this article. On the one hand, the quotas are to be considered from the administrative law point of view- they are the result of an administrative decision and their distribution is regulated by the code of administrative procedure. On the other hand, the legislator allowed the possibility of the civil law turnover. In Poland the legislator allows permanent and temporary alienation of individual quotes. In the case of permanent alienation, regulations pertaining to the contract of sale are applied; in the case of turning them over for somebody else's use - those concerning the contract of lease. Taking the above into account, one may observe that quotas for production of milk are of dual nature. In the relations: farmer - the Agricultural Market Agency, there is no doubt they are regulated by administrative law. Yet, in the case of appearing in the turnover they are the qualifications of a certain material worth, which requires the application of civil law. 